\title{
PENGARUH PENAMBAHAN MINYAK KELAPA MURNI (VIRGIN COCONUT OIL/VCO) TERHADAP PENAMPILAN PRODUKSI AYAM BROILER FASE FINISHER
}

\section{EFFECT OF PURE COCONUT OIL (VCO) ADDITION ON PRODUCTION PERFORMANCE OF CHICKEN BROILER AT FINISHER PHASE}

\author{
Paskalis Robinson \\ Program Studi Peternakan Fakultas Pertanian dan Peternakan, Universitas Satya Wiyata \\ Mandala Nabire \\ Jl. Sutamsu SH,Kalibobo-Nabire \\ Penulis korespondensi email : silakpas@gmail.com \\ \begin{tabular}{l|l} 
Diterima : 28 Desember 2017 & Disetujui : 12 Januari 2018
\end{tabular}
}

\begin{abstract}
Intisari
Penelitian ini mengenai Pengaruh Penambahan minyak kelapa murni (Virgin coconut oil) terhadap Penampilan Produksi Ayam Broiler Fase Finisher. Penelitian ini dilaksanakan pada tanggal 10 Maret sampai 5 April 2017 di Kampung Kaliharapan Distrik Nabire Kabupaten Papua. Penelitian ini didesain dengan menggunakanRancangan Acak Lengkap (RAL) dengan empat perlakuan dan setiap perlakuan mendapat pengulangan 5 (lima) kali sehingga diperoleh 20 satuan percobaan, setiap satuan percobaan terdiri atas 3 (tiga) ekor ayam. Perlakuan yang diuji yaitu pemberian berbagai dosis minyak kelapa murni yang dicampurkan ke dalam air minum yaitu: Tanpa minyak kelapa murni sebagai control, Dosis $5 \mathrm{cc} / 100$ ekor ayam, Dosis $10 \mathrm{cc} / 100$ ekor ayam dan Dosis $15 \mathrm{cc} / 100$ ekor/ayam. Variabel yang diamati adalah. Pertambahan bobot badan (gr/ ekor/ hari), Konsumsi ransum (gr/ ekor/ hari) dan Konversi Ransum (FCR). Data dianalisis secara eksperimen, jika terjadi perbedaan akan dilaksanakan uji lanjut dengan Uji Jarak Berganda dari Duncan. Hasil Penelitian menunjukkan bahwa Hasil penelitian menunjukkan bahwa semua perlakuan yang diberi VCO dapat meningkatkan pertambahan bobot badan ayam broiler yaitu peningkatan secara nyata terjadi mulai dari minggu V sampai VII, lebih efesien dalam mengkonsumsi ransum dan semakin tinggi dosis yang diberikan semakin rendah angka konversi ransum. Dari Hasil penelitian dapat disimpulkan bahwa Penambahan VCO berpengaruh nyata terhadap peningkatan bobot badan dan penurunan angka konversi ransum ayam broiler fase Finisher. Semakin tinggi dosis yang diberikan cenderung meningkatkan bobot badan dan menurunkan angka konversi ransum. Dosis penambahan VCO yang terbaik atau yang lebih efisien untuk ayam broiler fase Finisher adalah $15 \mathrm{cc} / 100$ ekor ayam.
\end{abstract}

Kata Kunci : Ayam Broiler fase Finisher, minyak kelapa murni, pertambahan bobot badan, konsumsi ransum dan konversi rasum 


\begin{abstract}
This study concerns the Effect of Addition of virgin coconut oil on Production performance at the Boiler Finisher Phase. The study was conducted on March 10 to April 5, 2017, at Kampung Kaliharapan Nabire District, Papua Province. This research was designed using Randomized Complete Design with four treatments and each treatment got 5 repetitions so that 20 units of the experiment were obtained, each the experiment unit consisted of 3 (three) chickens. The tested treatment is giving of various doses of pure coconut oil mixed with drinking water that is: Without pure coconut oil as control, $5 \mathrm{cc} / 100$ dose chicken, Dosage $10 \mathrm{cc} / 100$ chicken, and Dosage $15 \mathrm{cc} / 100$ head/ chicken. The observed variable is Weight gain (gr / head / day), feed consumption (gr / head / day) and Feed conversion (FCR). The data were analyzed experimentally if there was any difference it would be carried out the further test with Duncan Multiple Test. The results of the study showed that all treatments treated with VCO could increase the body weight of chicken broiler, ie, increase significantly occurred from week V to VII, more efficient in consuming feed and the higher the doses given the lower the feed conversion rate. From the results of this study, it can be concluded that the addition of VCO has a significant effect on the increase of body weight and the decrease of the feed conversion rate at broiler Finisher phase. The higher given dose tends to increase body weight and decrease the feed conversion rate. The best or more efficient VCO dosage for finisher phase of broiler chicken is $15 \mathrm{cc} /$ 100.
\end{abstract}

Keywords: Chicken Broiler, phase Finisher, pure coconut oil, body weight gain, feed consumption and conversion

\title{
PENDAHULUAN
}

Usaha ternak ayam broiler merupakan salah satu jenis usaha peternakan yang memiliki prospek cukup cerah untuk dikembangkan. Hal ini disebabkan oleh semakin meningkatnya kebutuhan masyarakat akan protein hewani yang sejalan dengan bertambahnya populasi penduduk dan semakin meningkatnya kesadaran masyarakat akan pentingnya gizi. Namun perlu disadari bahwa sumber protein terutama yang berasal dari produk hewani asal ternak belum mampu memenuhi kebutuhan masyarakat yang cenderung meningkat dari tahun ke tahun.
Untuk memenuhi kebutuhan tersebut, Pemerintah Indonesia melalui Direktorat Jenderal Peternakan Departemen Pertanian melakukan pembinaan pada beberapa jenis usaha peternakan yang mampu berproduksi dalam waktu relatif singkat seperti ayam broiler ( ayam pedaging ). Ayam broiler merupakan salah satu pilihan yang tepat karena memiliki karakteristik khusus, antara lain; pertumbuhan cepat, produksi daging cukup tinggi, siap dipotong pada usia relatif muda dan menghasilkan daging yang berserat lunak ( Murtidjo, 2006). 
Keberhasilan usaha peternakan ayam broiler yang dipelihara secara intensif sangat dipengaruhi oleh tatalaksana pemeliharaan, yang antara lain pengaturan jumlah maupun mutu ransum yang diberikan. Dalam pembuatan ransum ayam broiler biasanya menggunakan bahan baku yang berasal dari nabati dan hewani, dengan tujuan untuk saling mengisi kekurangan zat makanan tertentu dalam bahan pakan.

Ransum yang diberikan kepada ayam broiler tidak perlu berlebihan akan tetapi yang terpenting adalah kecukupan dan keseimbangan zat-zat makanan dan energi yang terkandung di dalamnya hendaknya sesuai dengan kebutuhan ternak. Maksud utama pemberian ransum untuk ayam broiler yaitu : untuk kehidupan pokok, menjamin pertambahan bobot badan, pertumbuhan bulu dan produksi telur. Namun seringkali ransum yang diberikan tidak efisien penggunaannya karena adanya gangguan fisiologis pada organ ternak yang mengakibatkan daya cerna menjadi rendah.

Penambahan minyak kelapa murni ke dalam air minum atau ransum diharapkan mampu memberi solusi dalam mengatasi berbagai persoalan yang berhubungan dengan upaya peningkatan produksi ayam broiler, karena kandungan gizi yang ada pada minyak kelapa murni relatif lengkap seperti asam laurat, asam kaproat asam kaprat, asam miristat dan asam palmitat. Menurut Price (2003) menyatakan bahwa zat yang terkandung di dalam minyak kelapa murni dapat berfungsi sebagai antivirus, antibakteri, dan antiprotozoa dan juga sebagai antioksidan dan nutrisi lainya yang dapat bermanfaat bagi pertumbuhan ayam broiler yang secara ekonomis menguntungkan dibanding penggunaan obat-obatan dan vitamin lainnya.

Sistem pemeliharaan yang dilakukan oleh petani ternak dalam usaha pemeliharaan ayam broiler umumnya digolongkan sebagai system pemeliharaan modern atau sistem intensif. Namun demikian bukan berarti ternak yang dipelihara terbebas dari penyakit yang berakibat terganggunya organ tubuh terutama organ pencernaan sehingga daya cerna terhadap ransum menjadi rendah. Hal ini akan berpengaruh pada pertambahan bobot badan, sehingga produktivitas ternak menjadi tidak optimal.

Sehubungan dengan hal tersebut, perlu dilakukan pengujian penggunaan minyak kelapa murni ke dalam air minum ayam broiler. Permasalahannya adalah pada dosis berapa yang dapat memberikan pertambahan bobot badan optimal belum 
diketahui. Oleh karena itu perlu dilakukan minyak kelapa murni pada ayam broiler. penelitian pemberian berbagai dosis

\section{METODE PENELITIAN}

\section{Lokasi dan Waktu}

Penelitian ini dilaksanakan pada tanggal 10 Maret sampai 5 April 2017 di Kampung Kaliharapan Distrik Nabire, Propinsi Papua.

\section{Alat dan Bahan}

Alat yang digunakan adalah Kandang individual sebanyak 20 buah dengan ukuran, panjang $50 \mathrm{~cm}$, lebar 60 $\mathrm{cm}$ dan tinggi $100 \mathrm{~cm}$,Wadah tempat pakan sebanyak 20 buah,Tempat minum $\begin{array}{llll}\text { kapasitas } & 600 \mathrm{ml} & \text { sebanyak } & 20\end{array}$ buah,Sprayer 1 unit,Spuit kapasitas $1 \mathrm{ml}$ sebanyak 4 buah, Literan kapasitas 1 liter sebanyak 1 buah,Timbangan duduk $\begin{array}{lllll}\text { kapasitas } & 10 \quad \mathrm{~kg} & \text { sebanyak } & 1\end{array}$ buah,Timbangan gantung kapasitas 50 kg,Bohlam 15 watt sebanyak 20 buah,Thermometer 1 buah sedangkan bahan yang dibutuhkan adalah Ayam broiler fase finisher sebanyak 60 ekor, Minyak kelapa murni atau Virgin Coconut Oil (VCO) ,Ransum ayam 511 sebanyak 3 zak dan 512 sebanyak 3 zak, Desinfektan 1 botol,Kapur aktif $3 \mathrm{~kg}$ dan detergent.

\section{Analisis Data}

Metode yang digunakan dalam penelitian ini adalah metode eksperimen

\section{Rancangan Percobaan}

Penelitian ini didesain dengan menggunakanRancangan Acak Lengkap (RAL) dengan empat perlakuan dan setiap perlakuan mendapat pengulangan 5 (lima) kali sehingga diperoleh 20 satuan percobaan, setiap satuan percobaan terdiri atas 3 (tiga) ekor ayam. Perlakuan yang diuji yaitu pemberian berbagai dosis minyak kelapa murni yang dicampurkan ke dalam air minum yaitu:

Po = Tanpa minyak kelapa murni sebagai kontrol

$\mathrm{P} 1=$ Dosis $5 \mathrm{cc} / 100$ ekor ayam

$\mathrm{P} 2=$ Dosis $10 \mathrm{cc} / 100$ ekor ayam

$\mathrm{P} 3=$ Dosis $15 \mathrm{cc} / 100$ ekor/ayam

Secara matematis Model statistik RAL menurut Sastrosupadi (2000) adalah:

$$
\text { Yij } \quad=\pi+T i+C i j
$$

Dimana:

Yij = Respon atau nilai pengamatan dan perlakuan ke-i dan ulangan ke-j

$\pi \quad=$ Nilai tengah umum

$\mathrm{Ti}=$ Pengaruh perlakuan ke- $\mathrm{i}$

$\mathrm{Cij}=$ Pengaruh galat percobaan dari perlakuan ke-i dan ulangan ke-j Data dianalisis dengan analisis sidik ragam, apabila diantara perlakuan terdapat perbedaan yang nyata maka 
dilanjutkan dengan Uji Jarak Barganda dari Duncan (DMRT).

\section{Teknik Budidaya Ayam Pedaging (Broiler)}

a. Mempersiapkan Kandang dan Peralatan:

- Membuat kandang postal (litter) yang dibagi menjadi 20 kotak dengan ukuran $\mathrm{P} \times \mathrm{L} \times \mathrm{T}$ berturutturut $50 \mathrm{~cm} \times 50 \mathrm{~cm} \times 100 \mathrm{~cm}$

- Melakukan sanitasi kandang dan peralatan

- Menata peralatan kandang sesuai kebutuhan

b. Teknik aplikasi minyak kelapa murni pada air minum

- Menghitung kebutuhan minyak kelapa murni (Virgin Coconut Oil/VCO) per ekor ayam dengan berpatokan pada standard dosis/100 ekor, kemudian dikalikan dengan banyaknya ayam dalam 1 kotak

- Mencampur minyak kelapa murni (Virgin Coconut Oil/VCO) dengan air pada penampang luar wadah tempat minum sesuai hasil perhitungan dengan menggunakan spuit.

- Menempatkan tempat air minum sesuai dengan blok yang telah diatur sesuai ketentuan c. Pemberiaan Makanan

Ransum diberikan secara terbatas, namun sesuai dengan standard kebutuhan (restriction) ayam pedaging (broiler)

d. Pengamatan

Variabel yang diamati adalah:

1). Pertambahan bobot badan (gr/ ekor/ hari)

Pertambahan bobot badan ayam diperoleh dari hasil penimbangan bobot badan akhir dikurangi dengan bobot badan awal dibagi jangka waktu penimbangan. Penimbangan dilakukan secara periodik sekali seminggu.

2). Konsumsi ransum (gr/ ekor/ hari)

Konsumsi ransum yaitu banyak ransum yang dikonsumsi dalam jangka waktu tertentu. Konsumsi ransum dapat dihitung dengan cara mengurangi jumlah ransum yang diberikan dengan jumlah ransum tersisa dan tercecer.

3). Konversi Ransum (FCR)

Konversi Ransum ransum diperoleh dengan membandingkan antara pertambahan bobot badan rata-rata dengan konsumsi ransum. 


\section{HASIL DAN PEMBAHASAN}

\section{Pertambahan Bobot Badan}

Tabel 1. Rataan Pertambahan Bobot Badan Ayam Broiler Fase Finisher (gram/ekor) setelah Penambahan berbagai Dosis Minyak Kelapa Murni (VCO) Dalam Air Minum

\begin{tabular}{ccccc}
\hline $\begin{array}{c}\text { Dosis Minyak kelapa } \\
\text { murni/VCO } \\
(\text { cc/100 ekor })\end{array}$ & \multicolumn{5}{c}{ Rataan Pertambahan Bobot Badan (gram/ekor) Minggu ke... } \\
\hline 0 & IV & V & VI & VII \\
\hline 5 & $154,666^{\mathrm{b}}$ & $394^{\mathrm{b}}$ & $723,33^{\mathrm{b}}$ & $1227,32^{\mathrm{b}}$ \\
10 & $165,33^{\mathrm{b}}$ & $406^{\mathrm{b}}$ & $812,67^{\mathrm{b}}$ & $1236,02^{\mathrm{b}}$ \\
15 & $168,67^{\mathrm{b}}$ & $418^{\mathrm{ab}}$ & $826^{\mathrm{b}}$ & $1285,22^{\mathrm{b}}$ \\
& $194,67^{\mathrm{a}}$ & $441,33^{\mathrm{a}}$ & $881,33^{\mathrm{a}}$ & $1395,34^{\mathrm{a}}$
\end{tabular}

Sumber : Hasil Olahan data Primer, 2017

Keterangan : huruf yang sama pada kolom tidak berbeda nyata

Berdasarkan data-data pada tabel

1, menunjukkan bahwa pemberian VCO memberikan pengaruh terhadap pertambahan bobot badan ayam broiler fase finisher pada akhir minggu IV,V, VI dan VII. Hasil penelitian menunjukkan bahwa semua perlakuan yang diberi VCO dapat meningkatkan pertambahan bobot badan ayam broiler yaitu peningkatan secara nyata terjadi mulai dari minggu $\mathrm{V}$ sampai VII. Pemberian minyak kelapa murni (Virgin Coconut Oil) dengan dosis $15 \mathrm{cc} / 100$ ekor menghasilkan pertambahan bobot badan yang berbeda nyata dibandingkan dengan kontrol (tanpa perlakuan minyak kelapa murni). Hal ini disebabkan karena kandungan asam laurat tinggi dalam minyak kelapa murni sangat bermanfaat menangkal virus, bakteri dan pathogen lain, serta membangun sistem kekebalan tubuh seperti halnya ASI (air susu ibu) juga mengandung asam laurat, Price (2003).

Menurut Soeharsono (1997), pada fase awal pertumbuhan ayam, kebutuhan air minum lebih besar dari zatzat makanan lainnya, sehingga mempercepat laju aliran makanan dalam saluran pencernaan. Diduga pemberian VCO melalui air minum dapat membantu memperlancar dan mempercepat laju aliran makanan dalam saluran pencernaan, mencegah timbulnya penyakit pada saluran pencernaan sehingga penyerapan zat-zat makanan lebih optimal. 


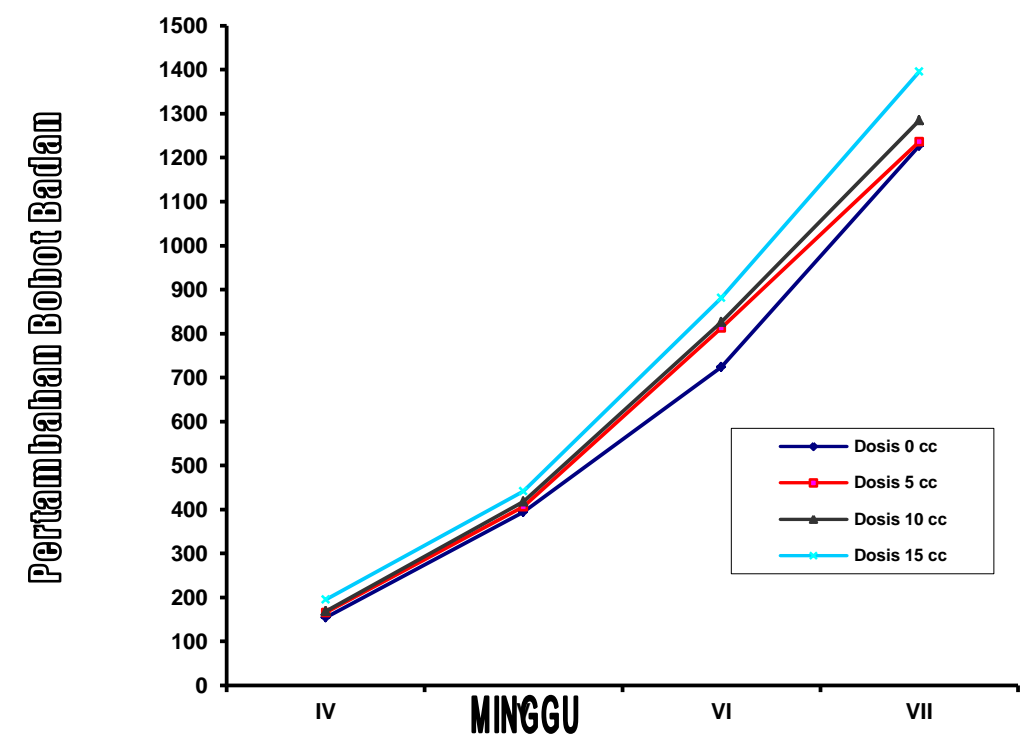

Gambar 1. Grafik Pertambahan Bobot Badan Setelah Pemberian berbagai Dosis Minyak Kelapa Murni (VCO) pada Minggu IV, V, VI, VII.

Grafik tersebut menunjukkan bahwa ayam broiler yang diberi VCO tumbuh lebih cepat dibandingkan dengan yang tidak diberi VCO. Pada minggu IV dan $\mathrm{V}$ pertumbuhan masih berlangsung lambat. Setelah masuk minggu ke VI dan VI mulai menunjukkan pertumbuhan yang lebih cepat. Pola pertumbuhan ayam broiler dari hasil percobaan ini, sesuai dengan pernyataan Kartasudjana et al. (2006) bahwa pertumbuhan tercepat terjadi pada umur $4-6$ minggu, setelah itu kembali lambat dan akhirnya konstan sampai mencapai dewasa.

\section{Konsumsi Ransum dan Konversi Penggunaan Ransum}

Hasil pengamatan konsumsi dan konversi ransum ayam broiler fase starter setelah penambahan berbagai dosis minyak kelapa murni (Virgin coconut oil/VCO) melalui air minum disajikan pada tabel berikut:

Tabel 2. Data Konsumsi Ransum dan Perhitungan Konversi Penggunaan Ransum

\begin{tabular}{ccc}
\hline $\begin{array}{c}\text { Dosis Minyak kelapa } \\
\text { murni/VCO } \\
(\text { cc/100 ekor })\end{array}$ & $\begin{array}{c}\text { Konsumsi Ransum } \\
(\text { gram/ ekor })\end{array}$ & $\begin{array}{c}\text { Konversi Penggunaan } \\
\text { Ransum }\end{array}$ \\
\hline 0 & $1874,04^{\mathrm{a}}$ & $1,386^{\mathrm{a}}$ \\
5 & $1961,9974^{\mathrm{a}}$ & $1,52^{\mathrm{a}}$ \\
10 & $1814,8^{\mathrm{a}}$ & $1,318^{\mathrm{a}}$ \\
15 & $1836,568^{\mathrm{a}}$ & $1,038^{\mathrm{b}}$ \\
\hline
\end{tabular}


Angka konversi ransum pada tabel 2, menunjukkan bahwa pemberian VCO dapat menurunkan angka konversi ransum. Angka konversi ransum yang paling rendah dihasilkan dari dosis VCO 15 cc/100 ekor. Semakin tinggi dosis VCO yang diberikan, cenderung menurunkan angka konversi ransum.

Konversi ransum secara umum dipengaruhi oleh konsumsi ransum, daya cerna, penggunaan zat-zat makanan, umur, dan genetik (Anggorodi, 1979). Angka konversi ransum yang lebih rendah akibat penambahan VCO menunjukkan bahwa ayam broiler fase finisher lebih efisien dalam memanfaatkan ransum. Hal ini terjadi karena VCO mengandung berbagai senyawa aktif, mineral dan vitamin yang dapat membantu meningkatkan daya cerna makanan bagi ayam broiler. Peningkatan daya cerna akan meningkatkan penyerapan zat-zat makanan, sehingga ransum dapat dimanfaatkan secara lebih efisien.

Angka konversi ransum dapat dijadikan tolok ukur dalam menentukan nilai manfaat dari ransum yang diberikan (Anggorodi, 1985). Semakin rendah nilai konversi ransum, maka semakin baik nilai manfaat ransum tersebut, karena ayam lebih efisien dalam memanfaatkan ransum. Jika ayam mampu memanfaatkan ransum yang lebih efisien berarti usaha ternak ayam tersebut lebih menguntungkan. Ditinjau dari aspek Konsumsi dan angka konversi ransum, maka dosis yang terbaik untuk ayam broiler fase Finisher adalah 15 cc/100 ekor. Pada dosis ini lebih efisien dibandingkan dengan dosis 5 dan 10 cc/100 ekor ayam.

\section{KESIMPULAN DAN SARAN}

\section{Kesimpulan}

Penambahan VCO ke dalam air minum berpengaruh nyata terhadap peningkatan bobot badan dan penurunan angka konversi ransum ayam broiler fase Finisher. Semakin tinggi dosis yang diberikan cenderung meningkatkan bobot badan dan menurunkan angka konversi ransum. Dosis penambahan VCO yang terbaik atau yang lebih efisien untuk ayam broiler fase Finisher adalah 15 cc/100 ekor ayam.

\section{Saran}

Perlu dilakukan percobaan lanjutan untuk mengetahui pengaruh Pemberian VCO terhadap pencegahan penyakit. 


\section{'DAFTAR PUSTAKA}

Anggorodi, R., 1979. Ilmu Makanan Ternak Umum. PT Gramedia, Jakarta.

Anggorodi, R., 1985. Ilmu Makanan Ternak Unggas, Kemajuan Mutakhir. Penerbit Universitas Indonesia ( UI). Akoso ,1998. KesehatanUnggas, panduan bagi petugas teknis penyuluh dan peternak.Penerbit Kanisius Yogyakarta.

Anggorodi, R., 1979. Ilmu Makanan Ternak Umum. PT Gramedia, Jakarta.

Anggorodi, R., 1985. Ilmu Makanan Ternak Unggas, Kemajuan Mutakhir. Penerbit Universitas Indonesia ( UI).

Brown, H.W.,1979. Dasar Parasitologi Klinis. PT. Gramedia,Jakarta

Cahyono, B., 1997. Ayam Buras Pedaging. Penerbit PT. Penebar swadaya

Retno, F.D. dkk., 1998. Penyakit penyakit Pada Ayam. Penerbit Angkasan Bandung

Komandoko, G., 2002. Pemeliharaan Ayam Produksi . Penerbit Absolut.

I Made Budi, 2004. Buah Merah. Penerbit Swadaya

Kusumamihardja, S., 1992. Parasit dan Parasitologi Pada Hewan Ternak dan Hewan Piaraan di Indonesia. Insitut Pertanian Bogor

Levine, N. D., 1990. Parasitologi Veteriner. Gadjah Mada Universitas Press.

Murtidjo B. A., 2006. Pedoman Beternak Ayam Pedaging. Yayasan Kanisius, Yogyakarta

Noble, E. R dan G.A. Noble., 1989. Parasitologi. Gadjah Mada Universitas Press
Rasyaf, M., 1992. Manajemen Peternakan Ayam Broiler. Penerbit PT. PenebarSwadaya.

Rindengan, B. dan H. Novarianto., 2006. Minyak Kelapa Murni (VCO). Penerbit Penebar Swadaya

Rumetor, 1989. Parasitologi Veternier. Bahan Ajar Fakultas Pertanian Universitas Cendrawasih Manokwari.

Soeharsono, 1997. Respon Broiler Terhadap Berbagai Kondisi Lingkungan. Universitas Padjajaran, Bandung.

Soenarto, 1986. Diktat Cacing dan Anthophoda Parasit. Faperta Uncen Manokwari.

Sutarmi, dan H. Rozaline., 2006. Taklukkan Penyakit Dengan VCO. Penerbit Penebar Swadaya

Tabbu, C. R., 1997. Penyakit Ayam dan Penanggulangannya Vol 1. Penerbit Kanisius Yogyakarta.

Tabbu, C. R., 1997. Penyakit Ayam dan Penanggulangannya Vol 2. Penerbit Kanisius Yogyakarta.

Wahyu J., 1988. Ilmu Nutrisi Unggas. Gadjah Mada University Press, Yogyakarta. 
